\title{
IS THE "U-SIGN" RADIOLOGIC FEATURE OF A POSTERIOR CRUCIATE LIGAMENT TIBIAL AVULSION FRACTURE?
}

\section{A IMAGEM DO "U-RADIOLÓGICO" É UM SINAL DA FRATURA- AVULSÃO TIBIAL LIGAMENTO CRUZADO POSTERIOR?}

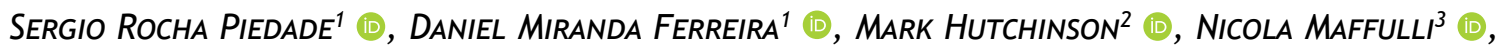 \\ MARTHA MARIA MISCHAN ${ }^{4}$ (D), PHILIPPE NEYRET ${ }^{5}$ (1) \\ 1. Universidade Estadual de Campinas, Faculdade de Ciências Médicas, Campinas, SP, Brazil. \\ 2. University of Illinois at Chicago, Chicago, IL, USA. \\ 3. Centre for Sports and Exercise Medicine, Barts and The London School of Medicine and Dentistry, Mile End Hospital, London, UK. \\ 4. Universidade Estadual Paulista, Instituto de Biociências, Departamento de Bioestatística, Botucatu, SP, Brazil. \\ 5. University of Lyon, Lyon, France.
}

\section{ABSTRACT}

Objective: By analyzing our cases of posterior cruciate ligament (PCL) tibial avulsion fracture, we noted that a U-shaped image was present in the anteroposterior plain radiographs view of the affected knee, even in cases where the profile view of the knee had been inconclusive as to tibial PCL avulsion fracture, a "hidden" fracture. Therefore, we aimed to investigate whether there was an anatomical correlation between this radiological $U$ sign and the tibial insertion of the PCL and to ascertain the intra- and inter-rater reliability of this sign in clinical practice. Methods: The data of the widths and heights area of the PCL tibial insertion area, and the $U$ sign area were measured and compared to the largest width of the tibia. Two moreover, the reliability and reproducibility of this imaging were analyzed. Results: The areas height of the $U$-sign area and the anatomical insertion area of the posterior cruciate ligament showed no difference, and both were topographically located in the two central quarters of the proximal end of the tibia. The radiographic assessment showed excellent Kappa agreement rates between interobserver and intraobserver, with high reliability and reproducibility. Conclusion: The $U$ sign is a radiographic feature of $P C L$ tibial avulsion fracture seen on the radiograph $\mathrm{AP}$ view, there is a high association between the ratios of the $U$-sign area height in the $\mathrm{X}$-ray and the anatomical height of the PCL tibial insertion site MRI with the largest width of the proximal tibia. The radiographic $U$ sign showed excellent rates of interobserver and intraobserver agreement with Kappa values higher than 0.8. Level of Evidence IV; Dignostic Studies - Investigating a Diagnostic Test.

Keywords: Posterior Cruciate Ligament. Fractures Avulsion; Knee; Radiography; Diagnosis.

\section{RESUMO}

Objetivo: Avaliando nossos casos de fratura-avulsão da inserção tibial do ligamento cruzado posterior, observamos que uma imagem em forma de U estava presente na radiografia plana anteroposterior do joelho afetado, mesmo nos casos em que a visão do perfil do joelho era inconclusiva quanto à fratura por avulsão do ligamento cruzado posterior (LCP) tibial, uma fratura "oculta". Portanto, buscamos investigar se havia uma correlação anatômica entre esse sinal radiológico U e a inserção tibial do LCP, além de verificar a confiabilidade intra e interexaminadores desse sinal na prática clínica. Métodos: Os dados das larguras e alturas da área de inserção tibial do LCP e da área do sinal U foram medidos e comparados com a maior largura da tíbia. Além disso, foram analisadas a confiabilidade e a reprodutibilidade dessa imagem. Resultados: A altura da área do sinal U e da área de inserção anatômica do ligamento cruzado posterior não mostraram diferença, e ambas estavam localizadas topograficamente nos dois quartos centrais da extremidade proximal da tíbia. A avaliação radiográfica mostrou excelentes taxas de concordância Kappa entre interobservador e intraobservador, com alta confiabilidade e reprodutibilidade. Conclusão: O sinal U é uma característica radiográfica da fratura por avulsão tibial do LCP que pode vista na radiografia AP. Existe uma alta associação entre as proporções da altura da área do sinal U na radiografia e da altura anatômica da inserção tibial do LCP RM local em relação à maior largura da tíbia proximal. O sinal radiográfico U mostrou excelentes taxas de concordância interobservador e intraobservador, com valores de Kappa superiores a 0,8. Nível de Evidência IV, Estudos Diagnósticos - Investigação de um exame para diagnóstico.

Descritores: Ligamento Cruzado Posterior; Fratura Avulsão; Joelho; Radiografia; Diagnóstico.

Citation: Piedade SR, Ferreira DM, Hutchinson M, Maffulli N, Mischan MM, Neyret P. Is the "U-sign" radiologic feature of a posterior cruciate ligament tibial avulsion fracture? Acta Ortop Bras. [online]. 2021;29(4):189-192. Available from URL: http://www.scielo.br/aob.

All authors declare no potential conflict of interest related to this article.

The study was conducted at the Department of Orthopedic and Traumatology, School of Medical Science, University of Campinas. Correspondence: Sergio Rocha Piedade. Rua Severo Penteado 131, apto 1, Campinas, SP, Brazil, 13025050. piedade@unicamp.br 


\section{INTRODUCTION}

The knee joint is a complex hinge joint that depends not only the structure of the bone but also the collateral and cructiate ligaments to maintain stability and structure. Physical and athletic demands such as running, jumping, acceleration/deceleration, changing direction, and absorbing forces are done with the knee at a certain degree of flexion which in turn exposes the ligaments to greater loads making them more vulnerable to injury. ${ }^{1}$ The posterior cruciate ligament $(\mathrm{PCL})$ is the primary stabilizer to posterior tibial translation and a secondary stabilizer versus rotation.

Avulsion fractures of the posterior cruciate ligament at its tibial insertion are one of the most common forms of isolated PCL injury, ${ }^{1-3}$ usually resulting from low energy trauma. ${ }^{4-7}$ At presentation, plain radiography is the first imaging exam performed, and generally plain radiographs of the knee are sufficient to diagnose avulsion fractures of the posterior cruciate ligament. Indeed, on lateral knee radiographs, avulsion of the tibial insertion of the posterior cruciate ligament appears as focal interruption of the posterior surface of the tibia. ${ }^{8}$ However, since PCL tibial avulsion is uncommon in clinical practice, some surgeons may not identify this injury on radiographs, ${ }^{9}$ for example when the avulsed bone may be hidden in the lateral view or appears anteriorly to its original anatomic position in lateral radiographic view of the knee. Henry Dejour, ${ }^{10}$ the French orthopedist, in a personal communication, suggested that avulsion fractures of the posterior cruciate ligament at its tibial insertion presented a U-shaped image on plain anteroposterior radiographs. The tibial insertion of the PCL is anatomically complex, but its shape and position seem to be consistent. ${ }^{11}$ The relationship between the $U$ sign and the tibial insertion of the PCL has not been systematically investigated. In clinical practice, we noted that our patients with a PCL avulsion fracture at the tibial insertion presented a U-shaped radiographic image in the anteroposterior view of the knee, even in cases in which the radiograph in the lateral view of the knee PCL had been inconclusive or unclear as to tibial avulsion fracture, a "hidden" fracture (Figure 1A, $\mathrm{B}$ and $\mathrm{C}$ ). We therefore aimed to establish whether it was possible to use this radiographic sign in clinical practice.

\section{MATERIALS AND METHODS}

From January 1997 to December 2005, 21 consecutive patients underwent surgical treatment for PCL avulsion at the tibial insertion site by the same surgeon. We had preoperative radiographs 19 out of these 21 patients, which constituted our study group. A control group was produced after evaluating $63 \mathrm{MRI}$ scans of patients that did not present, as a final imaging diagnosis, bone or soft tissue lesions of the knee. Based on magnetic resonance scans (Figure 2A, B, C) and anteroposterior radiographs of the knee (Figure 3), the width and height of the PCL tibial insertion area and the $U$ sign area at the avulsed tibial fracture site were measured, respectively, and expressed as a ratio of the largest width of the proximal tibia. This research work was approved by the University Ethics Committee, and an informed consent was obtained from the participants of this research and registered under the study number CAAE 32856620.0.0000.5404.
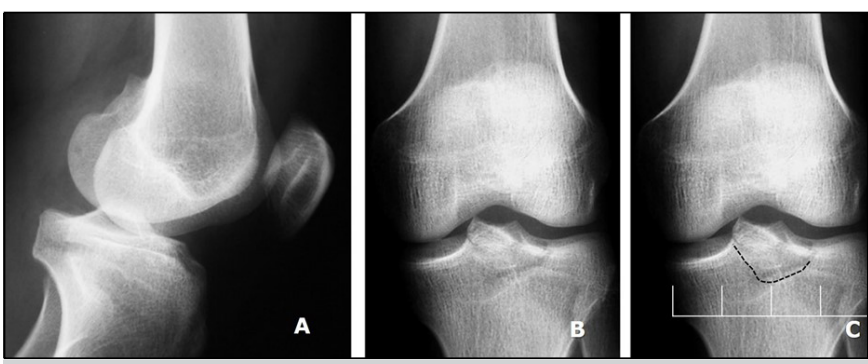

Figure 1. A "hidden" avulsion fracture of the posterior cruciate ligament of the left knee on the lateral view (Figure $1 \mathrm{~A}$ ) and the presence of the radiologic $\mathrm{U}$-sign (Figure 1B and $1 \mathrm{C}$-dotted line) in the anteroposterior X-ray.
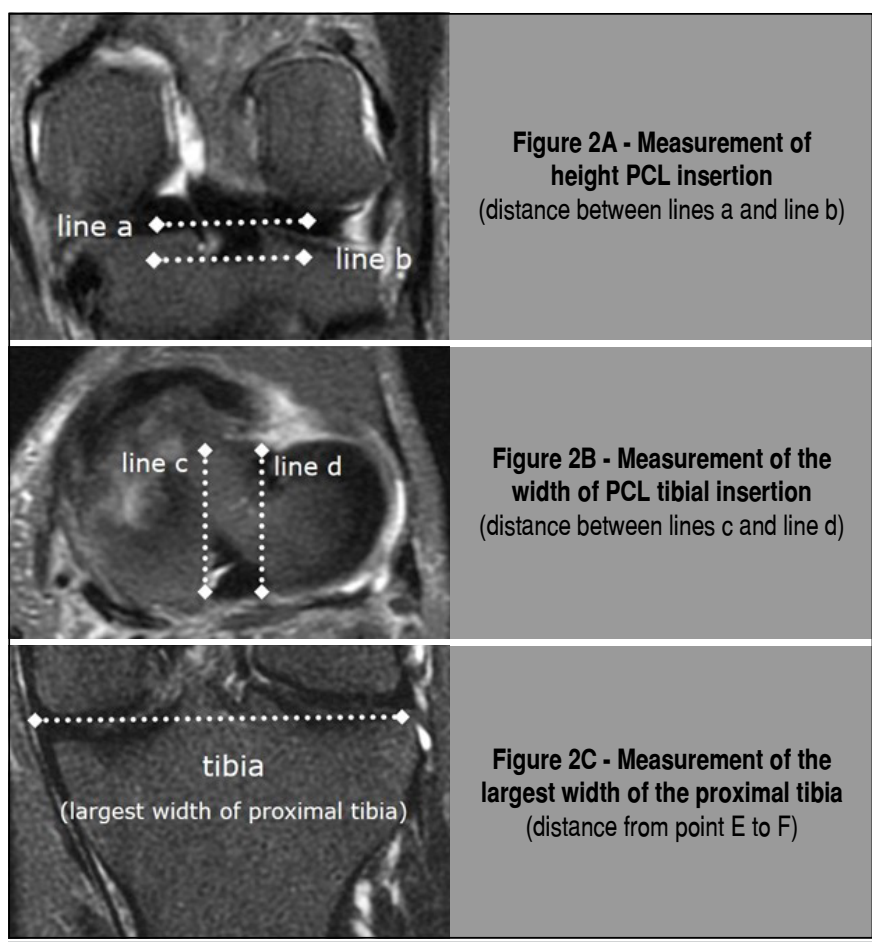

Figure 2. Measurements of height (2A), width (2B), and the largest width of the tibia (2C) performed on MRI scan.

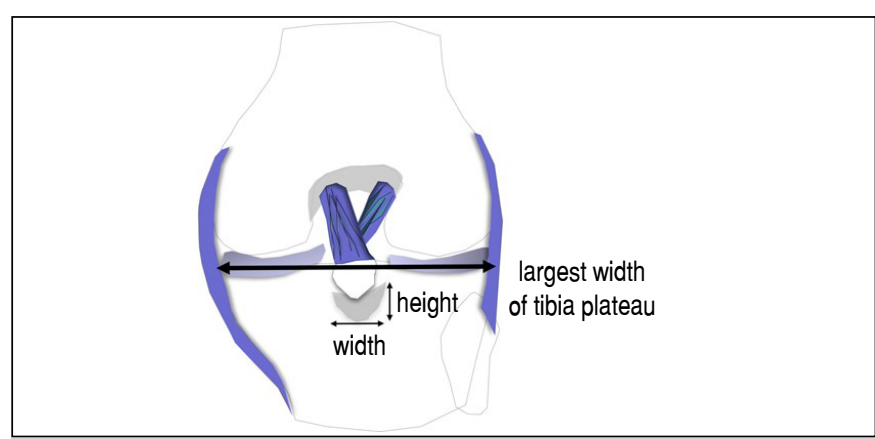

Figure 3. Scheme of measurement of width and height of the U-shaped radiological image and proximal tibial axis (radiological U-sign).

\section{Analysis of interrater reliability of radiological U-sign}

Two fellowship-trained musculoskeletal radiologists were invited to evaluate the presence of the $U$-shaped radiological image (radiological U sign) in 36 anteroposterior radiographs views of the knee joint. Radiographs consisted of case of PCL tibial avulsion fracture (50\%) and no bone injury (50\%). Results obtained were compared with the final surgical findings. The Kappa statistics was used to obtain inter-observer and intra-observer agreement of two expert radiologists. Interpretation of the agreement values was based on the method proposed by Landis and Koch. ${ }^{12}$

\section{Statistical analysis}

Based on the results, the analysis of variance was used to investigate the influence of the distribution of the data obtained in PCL tibial avulsion fracture group $(n=19)$ and MRI scan group (control group) ( $n=63$ ). The significance was set at $p<0.05$, and the data obtained from the two groups were tabulated (Table 1 and 2).

\section{RESULTS}

The descriptive characteristics of the two groups under exam are given in Tables 1 and 2. 
Table 1. Descriptive analysis of PCL tibial avulsion fracture group.

\begin{tabular}{c|c|c|c|c|c|c}
\hline & $\mathbf{n}$ & mean & std dev & sum & minimum & maximum \\
\hline tibia (proximal axis) & 19 & 50.28 & 14.98 & 955.34 & 31.60 & 93.21 \\
\hline U height & 19 & 7.82 & 2.52 & 148.62 & 5.11 & 14.04 \\
\hline U width & 19 & 19.34 & 6.39 & 367.47 & 10.85 & 36.00 \\
\hline Y1 (U width / tibial axis) & 19 & 38.91 & 8.44 & 739.22 & 20.61 & 54.85 \\
\hline Y2 (U heigth / tíbial axis) & 19 & 15.64 & 2.32 & 297.21 & 11.54 & 19.91 \\
\hline Y3 (area) & 19 & 161.88 & 105.35 & 3076.00 & 58.71 & 505.44 \\
\hline Y3 $^{*}$ & 19 & 2.22 & 0.13 & 42.15 & 2.02 & 2.50 \\
\hline Y4 (U width / U height) & 19 & 2.52 & 0.57 & 47.83 & 1.55 & 3.87 \\
\hline
\end{tabular}

* variable transformed to logarithms, aiming to homogenize the variances.

Table 2. Descriptive analysis of MRI Group (control group).

\begin{tabular}{c|c|c|c|c|c|c}
\hline & $\mathbf{n}$ & mean & std dev & sum & minimum & maximum \\
\hline tibia (proximal axis) & 63 & 7.52 & 0.66 & 474.09 & 5.40 & 8.70 \\
\hline height (PCL tibia insertion height) & 63 & 1.19 & 0.22 & 75.08 & 0.70 & 1.73 \\
\hline width (PCL tibia insertion width) & 63 & 1.44 & 0.25 & 90.97 & 0.90 & 2.00 \\
\hline Y1 (U width / tibial axis) & 63 & 19.24 & 3.17 & 1212.00 & 11.11 & 27.12 \\
\hline Y2 (U heigth / tíbial axis) & 63 & 15.93 & 3.28 & 1004.00 & 8.97 & 31.48 \\
\hline Y3 (area) & 63 & 1.72 & 0.43 & 108.25 & 0.98 & 2.89 \\
\hline Y3 $^{*}$ & 63 & 0.99 & 0.079 & 62.43 & 0.83 & 1.17 \\
\hline Y4 (U width / U height) & 63 & 1.25 & 0.33 & 79.04 & 0.60 & 2.00 \\
\hline
\end{tabular}

* variable transformed to logarithms, aiming to homogenize the variances.

On both plain radiographs and $\mathrm{MRI}$, the radiological $U$ sign and the PCL tibial insertion site were in the two central quarters of the proximal tibia (Figure 1C). There were no statistically significant differences between the mean height values of the tibial insertion area and that of the $U$ sign with the largest width of the proximal tibia $(p=0.72)$. However, the analysis revealed a statistical difference between the mean width values to the largest transverse width of the proximal tibia $(p<0.0001)$ (Table 3 and 4$)$.

Table 3. Analysis of variance, $F$ test and $p$-value of measures $Y 1, Y 2, Y 3$ and $Y 4$ obtained in both study groups.

\begin{tabular}{c|c|c|c}
\hline Measures & F test & P value & Variance \\
\hline$Y 1$ & 237.08 & $<0.0001$ & 20.5 \\
\hline$Y 2$ & 0.13 & 0.72 & 19.5 \\
\hline $3^{*}$ & 2648.21 & $<0.0001$ & 7.1 \\
\hline$Y 4$ & 147.45 & $<0.0001$ & 25.7 \\
\hline
\end{tabular}

Y1: U width/tibia; Y2: U height/tibia); Y3: area; Y4: U width/U height.

* Variables transformed into logarithms, aimed at homogenizing the variances.

Table 4. Comparative analysis between means of measures $Y 1, Y 2, Y 3$ and $Y 4$ obtained in both study groups.

\begin{tabular}{c|c|c|c|c}
\hline Groups & Y1 & Y2 & Y3 & Y4 \\
\hline PCL avulsion fracture & $38.91 \mathrm{a}$ & $15.64 \mathrm{a}$ & $161.88 \mathrm{a}$ & $2.52 \mathrm{a}$ \\
\hline MRI scan & $19.24 \mathrm{~b}$ & $15.93 \mathrm{a}$ & $1.72 \mathrm{~b}$ & $1.26 \mathrm{~b}$ \\
\hline
\end{tabular}

Y1: U width/tibia; Y2: U height/tibia; Y3: área; Y4: U width/U height.

* means followed by the same letter do not differ at $5 \%$.

The Kappa coefficient results presented excellent agreement in inter-observer and intra-observer analysis (Table 5 and 6).

Table 5. Kappa coefficients for the first and the second intra-observer evaluation compare to final surgical findings.

\begin{tabular}{c|c|c|c|c}
\hline intra-observers & Kappa index & confidence interval & p-value & agreement \\
\hline 1 & 0.925 & $1.0-0.737$ & $<0.001$ & excellent \\
\hline 2 & 0.851 & $1.0-0.662$ & $<0.001$ & excellent \\
\hline
\end{tabular}

Table 6. Kappa coefficients for the first and the second evaluation compare to final surgical findings.

\begin{tabular}{c|c|c|c|c}
\hline interobserver & Kappa index & confidence interval & p value & agreement \\
\hline first evaluation & 0.889 & $1.0-0.7$ & $<0.001$ & excellent \\
\hline second evaluation & 0.888 & $1.0-0.7$ & $<0.001$ & excellent \\
\hline
\end{tabular}




\section{DISCUSSION}

The most important findings of this study are that the $U$ sign is a radiographic feature of the area of $P C L$ tibial avulsion fracture seen on the radiograph AP view. There is a high association between the ratios of the $U$-sign height area in the $\mathrm{X}$-ray and the anatomical height of the PCL tibial insertion site MRI with the largest width of the proximal tibia. Moreover, their topography is consistently situated in the two central quarters of the proximal tibia (Figure $2 \mathrm{C}$ ). Moreover, this radiographic sign exhibits intra and inter-observer characteristics, with excellent agreement rates between inter and intra-observer analysis with Kappa values higher than 0.8, confirming its high reproducibility and applicability.

Tibial avulsion fracture of the PCL are uncommon, ${ }^{13}$ and precise diagnosis is necessary to define the optimal treatment for each specific patient.

The posterior surface of the tibia has a unique tridimensional anatomy, to which several structures converge, including the tibial plateau, the posterior intercondylar fossa, and the posterior cortex. The posterior cruciate ligament inserts into a central inclined depression between the medial and lateral parts of the tibial plateau, distinct from the vertical cortex of the tibia. ${ }^{13}$

A tomography with three-dimensional reconstruction provides great details on the size of the bone fragment, its displacement, and presence of comminution, helping to better plan the therapeutic approach. ${ }^{14}$ However, it involves ionizing radiations, and in this respect it is more invasive than plain radiography.
When bone avulsion of the posterior cruciate ligament at its tibial insertion is associated with fragment displacement, surgery should be planned, since it generally produces better results than conservative management. . $^{15-17}$

To our knowledge, the literature has not yet investigated a correlation between the dimensions of the tibial insertion of the PCL with the radiographic features of tibial avulsion fractures on the anteroposterior radiographs of the knee. Therefore, the $U$ sign can alert physicians to the presence of the injury even when a "hidden" PCL tibial avulsion fracture is not visualized in lateral radiographic views (Figure 1A). Moreover, when the avulsed bone appears anteriorly to its original anatomic position in the lateral radiographic view of the knee, the orthopedist might inaccurately diagnose it as a fracture of the tibial plateau or a bone avulsion of the anterior cruciate ligament. ${ }^{18,19}$ In this context, the $U$ sign seems to offer valuable information to supplement the clinical and imaging diagnosis of PCL avulsion fractures.

\section{CONCLUSION}

The $U$ sign is a radiographic feature of PCL tibial avulsion fracture seen on the radiograph AP view. There is a high association between the ratios of the $U$-sign height in the $\mathrm{X}$-ray, and the anatomical height of the PCL tibial insertion site MRI with the largest width of the proximal tibia. The radiographic $U$ sign showed excellent rates of interobserver and intraobserver agreement with Kappa values higher than 0.8 .

AUTHORS' CONTRIBUTIONS: Each author contributed individually and significantly to the development of this article. SRP: substantial contribution to the study in its conception, design, data collection, analysis and interpretation of data, writing and critical review of its intellectual content, and approval of the final version of the manuscript to be published; DMF: data collection, analysis and interpretation, writing and critical review of its intellectual content, and approval of the final version of the manuscript to be published; $\mathrm{MH}$ : writing and critical review of its intellectual contentand approval of the final version of the manuscript to be published; NM: final approval of the version of the manuscript to be published; MMM: analysis, data interpretation and final approval of the manuscript version to be published; PN: writing and critical review of its intellectual content, and approval of the final version of the manuscript to be published.

\section{REFERENCES}

1. Flandry F, Hommel G. Normal anatomy and biomechanics of the knee. Sports Med Arthrosc Rev._2011;19(2):82-92.

2. Bonin N, Jeunet $L$, Obert $L$, Dejour D. Adult tibial eminence fracture fixation: arthroscopic procedure using K-wire folded fixation. Knee Surg Sports Traumatol Arthrosc. 2007;15(7):857-62.

3. Katsman A, Strauss EJ, Campbell KA, Alaia MJ. Posterior cruciate ligament avulsion fractures. Curr Rev Musculoskelet Med. 2018;11(3):503-9.

4. Hesse E, Bastian L, Zeichen J, Pertschy S, Bosch U, Krettek C. Femoral avulsion fracture of the posterior cruciate ligament in association with a rupture of the popliteal artery in a 9-year-old boy: a case report. Knee Surg Sports Traumatol Arthrosc. 2006;14(4):335-9.

5. Clanton TO, Delee JC, Sanders B, Neidre A. Knee ligament injuries in children. J Bone Joint Surg Am. 1979;61(8):1195-201.

6. Al-Ahaideb A. Posterior cruciate ligament avulsion fracture in children: a case report with long-term follow-up and comprehensive literature review. Eur J Orthop Surg Traumatol. 2013;23 (Suppl 2):S257-60.

7. Piedade SR, Mischan MM. Surgical treatment of avulsion fracture of the knee PCL tibial insertion: experience with 21 cases. Acta Ortop Bras. 2007;15(5):272-5.

8. Hoogervorst P, Gardeniers Jwm, Moret-Wever S, Van Kampen A. Pseudo-arthrosis repair of a posterior cruciate ligament. Knee Surg Sports Traumatol Arthrosc. 2010;18(11):1612-6.

9. Meyers $\mathrm{MH}$. Isolated avulsion of the tibial attachment of the posterior cruciate ligament of the knee. J Bone Joint Surg Am. 1975;57(5):669-72.

10. Dejour H. Lesões ligamentares do joelho. Proceedings of the $3^{\text {rd }}$ Jornada Catarinense de Fisioterapia Ortopedica e Traumatologica; 1998 May 27-30; Joinvile, SC.
11. Tajima G, Nozaki M, Iriuchishima T, Ingham SJ, Shen W, Smolinski P, Fu FH. Morphology of the tibial insertion of the posterior cruciate ligament. J Bone Joint Surg Am. 2009;91(4):859-66.

12. Landis JR, Koch GG. The measurement of observer agreement for categorical data. Biometrics. 1977;33(1):159-74.

13. Moorman CT 3rd, Zane MSM, Bansai S, Cina SJ, Wickiewicz TL, Warren RF, Kaseta MK. Tibial insertion of the posterior cruciate ligament: a sagital plane analysis using gross, histologic, and radiographic methods. Arthroscopy. 2008;24(3):269-75.

14. Nikiforidis $P$, Babis G, Kateros K, Vlamis J, Korres DS. Isolated avulsion fracture of the tibial attachment of the posterior cruciate ligament. Eur J Orthop Surg Traumatol. 2000;10(4):257-59.

15. Deehan DJ, Pinczewski LA. Arthroscopic reattachment of an avulsion fracture of the tibial insertion of the posterior cruciate ligament. Arthroscopy. 2001;17(4):422-5.

16. Horas U, Meissner SA, Heiss C, Schnettler R. Arthroscopic fixation of posterior cruciate ligament avulsion fractures: a new minimally invasive technique. Knee Surg Sports Traumatol Arthrosc. 2010;18(6):781-3.

17. Joshi S, Bhatia C, Gondane A, Rai A, Singh S, Gupta S. Open reduction and internal fixation of isolated posterior cruciate ligament avulsion fractures: clinical and functional outcome. Knee Surg Relat Res. 2017;29(3):210-6.

18. Griffith JF, Antonio GE, Tong CW, Ming CK. Cruciate ligament avulsion fractures. Arthroscopy. 2004;20(8):803-12.

19. Nizlan MN, Suhail A, Samsudin OC, Masbah O. An unusual radiographic presentation of posterior cruciate ligament avulsion fracture. Med J Malaysia. 2004;59(Suppl F):65-8. 